\title{
Research upon the quality assurance of the rolling-mill rolls and the variation boundaries of the chemical composition ${ }^{(\cdot)}$
}

\author{
I. Kiss*
}

Abstract

Keywords

\begin{abstract}
The cast-iron rolls must present higher hardness at the rolling surface and lower in the core and the necks, adequate with mechanical resistance and in the high work temperature. If in the zone of the rolling surface, the hardness is guarantied by the irons structure, through the cementite quantities, the core of rolls must contain graphite, to assure this property. Starting from the lamination equipments aspects, from the form of rolls, of the technological interest zones and the structure, which assures the exploitation property, it was establish, through modeling, to the mathematical description of a direct influences, and in final, through successive determinations, to an optimum. One of the parameters, which are determined the structure of the irons destined for rolls casting, is the chemical composition, which guaranties the exploitation properties of the each roll in the stand of rolling mill. The realization of optimum chemical compositions of the cast-iron can constitute a technical efficient way to assure the exploitation properties, the material from which the rolling mills rolls are manufactured having an important role in this sense. Although the manufacture of rolls is in continuously perfecting, the requirements for superior quality rolls are not yet completely satisfied, in many cases, the absence of quality rolls preventing the realization of quality laminates or the realization of productivities of which rolling mills are capable. This paper presents an analysis of the main alloying elements from chemical composition, the influences upon the mechanical properties of the cast-iron rolls, and presents also some graphical addenda. Using the Matlab calculation and graphical programs we determinate some correlations between the hardness (on the working surface and on necks) and the chemical composition. Using the double and triple correlations is really helpful in the foundry practice, as it allows us to determine variation boundaries for the chemical composition, in view the obtaining the desired and optimal values of the hardness of this very important metallurgical equipments. The enunciation of some mathematically modeling results, described through a number of multi-component equations determined for the spaces with 3 the and 4 dimensions, as well as the generation of some regression surfaces, of some curves of levels and volumes of variation, can be represented and interpreted by technologists and can be considerate diagrams of correlation between the analyzed variables. From this point of view the research is inscribes in context of scientific capitalization of the process and the industrial technologies optimizations, on the way of the analysis and the mathematical experiment.
\end{abstract}

\section{Investigación al aseguramiento de calidad de los cilindros de laminador y de los límites de la variación de la composición química}

Resumen

\begin{abstract}
Los cilindros o rodillos de laminación de función deben presentar una dureza más alta en su superficie y menor en el núcleo y el cuello del cilindro, adecuados a la resistencia mecánica y a la alta temperatura de trabajo. Si en la zona de la superficie de rodillo, la dureza se garantiza por las cementita existente en la estructura, el núcleo del cilindro debe tener grafito para asegurar la característica deseada. A partir de consideraciones sobre los equipos de la laminación, forma de los cilindros de laminación, zonas tecnológicas del interés y de la estructura, que asegura la característica de la explotación, se estableció un modelo que da una descripción matemática de las influencias directas y, finalmente, mediante determinaciones sucesivas, permite establecer un óptimo. Uno de los parámetros, que determinan la estructura del material de los cilindros de laminación es su composición química, que garantiza las características de la explotación de cada cilindro en el laminador. El empleo de las composiciones químicas de colada, óptimas, puede ser una manera técnicamente eficiente de asegurar las características de la explotación; el material de fabricación de los cilindros juega un papel importante. Aunque la fabricación de cilindros es objeto de una mejora continua, los requisitos de la máxima calidad de los cilindros no se cumplen totalmente, en muchos casos, lo que impide la obtención de la calidad que podría obtenerse si dicha calidad de los cilindros fuera la adecuada En este trabajo, se analiza la influencia de los principales elementos de aleación en las características mecánicas de los rodillos con una addenda gráfica. Empleando Matlab como herramienta de cálculo, los programas gráficos permiten establecer algunas correlaciones entre la dureza (en la superficie y cuello de los cilindros) y la composición química. El empleo de correlaciones
\end{abstract}

(·) Trabajo recibido el día 11 de diciembre de 2007 y aceptado en su formna final e dñia 4 de Febrero de 2008.

* University Politehnica-Timisoara, Faculty Of Engineering-Hunedoara, Department of Engineering \& Management, Romania. 
dobles y triples es realmente provechoso en la práctica de la fundición, pues permite la determinación de los límites de la variación admisible en la composición química para la obtención de los valores deseados y los óptimos de la dureza de estos importantes equipos metalúrgicos. El enunciado de algunos resultados, obtenidos matemáticamente del modelo, descrito con un número de ecuaciones multi-componente determinadas para los espacios de 3 y 4 dimensiones, así como la generación de algunas superficies de regresión de curvas de niveles y de volúmenes de variación, se pueden representar e interpretar por los tecnólogos y se pueden considerar como los diagramas de la correlación entre las variables analizadas. Desde este punto de vista, la investigación se inscribe en el contexto de una capitalización científica del proceso y de optimización de las tecnologías industriales, como vía de análisis y experimentación matemáticas.

Palabras clave Cilindros de laminación; Elementos de aleación; Dureza; Composición química; Modelización matemática.

\section{PRELIMINARY NOTES}

The technological manufacturing process of the rolling mills cylinders, as well as the quality of material used in manufacturing them, can have a different influence upon the quality and the safety in the exploitation. This proposal approaches the issue of quality assurance of the rolling mills cylinders, from the viewpoint of the quality of materials, which feature can cause duration and safety in exploitation.

In these sense, the research was propose to analyze the durability in industrial exploitation of rolling mills cylinders, materialized from prism of the optimization of the manufacturing technology of the cast-iron rolls, using the electronic calculus technique as the modeling phenomenon and mathematical interpretation of the technological processes ${ }^{[1-5]}$. The mathematical modeling establishes a methodology for the determination of the technological parameters values, for which a mechanical characteristic (the hardness) has the desirable values. Because is disposed of real data, the optimization model is based on industrial data, obtained from cast-iron rolling mills cylinders. Their analysis shall lead to the optimization pattern, through the prism of the multi-component correlations, enounced by mathematical formulae. The experimented durability research, as well as the optimization of the manufacturing technology, allows the conclusion of direct results for the rolls ${ }^{[5-7]}$. The beneficiaries of these results are the manufactured units, as well as the exploits units.

Nodular graphite cast iron rolls are so superior in wear resistance to that of cast steel rolls that they are specially adapted for roughing and intermediate plate mills and rod or bar mill rougher. As a result of the spherical form of the graphite, these iron rolls are much stronger than rolls of the clear-chill type and the gradual fall in hardness is an added advantage. The nodular-graphite rolls combine the advantages resulting from the presence of graphite with the good properties of steel. Nodular-graphite rolls are, consequently, very resistant to breakage and are replacing both steel rolls and rolls of flake-graphite irons. As such, these rolls are particularly suitable for strip mills, also bar billet mills, and are being increasingly used for other

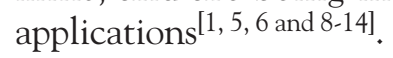

The rolls must present higher hardness at the rolls working surface and lower hardness in the core and on the necks, adequate with the mechanical resistance and in the high work temperatures. If in the crust the hardness is assured by the quantities of cementite from the structure of the irons, the core of the rolls must contain graphite to assure these properties. The improved mechanical properties increase its resistance to breakage from physical load, or mechanical and thermal shock far above that of grey iron. The corrosion resistance of ductile iron is equal or superior to grey cast iron and to cast steel in many corrosives. Its wear resistance is comparable to some of the best grades of steel and superior to grey irons in heavy load or impact load situations. Because it can be cast with the same low cost procedures used for grey iron it is considerably less expensive than cast steel and only moderately more expensive than grey iron.

The nodular cast iron rolls are characterized by the nodular shaped graphite in the microstructure. Through adjusting the alloy elements of nickel, chrome and molybdenum and heat treatment technique, the different type of rolls of popular nodular graphite cast iron. Large scale alloyed nodular graphite cast iron, pearlitic nodular graphite cast iron and acicular nodular graphite cast iron can be manufactured. All these types of rolls have high strength, excellent thermal properties and resistance to accidents and there is very little hardness drops in the surface work layer.

This type of material may be used to produce large scale rolls in double pouring process. The barrel of rolls has high hardness while the neck has high toughness, so these types of rolls exhibit the properties of high thermal stability and resistance to wear. As the characteristics of any casting are influenced by the microstructure that is formed during the solidification in the casting form, and under the influence of the cooling speed, the main criteria, which determines the 
RESEARCH UPON THE QUALITY ASSURANCE OF THE ROLLING-MILL ROLLS ANDTHE VARIATION BOUNDARIES OF THE CHEMICAL COMPOSITION INVESTIGACIÓN AL ASEGURAMIENTO DE CALIDAD DE LOS CILINDROS DE LAMINADOR Y DE LOS LÍMITES DE LA VARIACIÓN DE LA COMPOSICIÓN QUÍMICA

mechanical properties of the rolls is the structure. All structural components can be found in cast iron rolls, each of the components having it own well-determined hardness. One of the parameters, which are determined the structure of the irons destined for rolls casting, is the chemical composition. If we do not respect this composition, which are guarantied the exploitation properties of the each roll in the stand of rolling mill, leads to rejection of this ${ }^{[1,5}$ and 6$]$.

All FNS type rolls (nodular-irons rolls, medium hard classes) are alloyed especially with chrome, nickel and molybdenum, in different percentages. The irons destined to these cast rolls belong to the class of low alloyed irons, with reduced content of these elements. The technological instructions firmly state the elements required to rise the quality of rolls. In this case, the contents of these elements stand between large limits. Also, the contents of these alloying elements can be reduced due to the strong effect of the magnesium from the nodulising agent, upon the structure and the form of the graphite ${ }^{[1,5,6}$ and 10-14].

This study analyses iron rolls cast in the simplex procedure, in combined forms (iron chill, for the crust and modeling sand, for the necks of the rolls). The research included rolls from the medium-hard class, with hardness, between 33-59 Shore units (219-347
Brinell units) for the 0 and 1 hardness class, measured on the crust, respectively 59-75 Shore units (347-550 Brinell units), for the class 2 of hardness ${ }^{[1,5}$ and 6$]$. The recommended hardness of these, on the crust, as well as on the necks and in the core of rolls, fixed by the standards, is presented in table $\mathrm{I}^{[1,5}$ and 6$]$. The recommended chemical composition for the mediumhard class rolls, cast from lamellar graphite iron (FS type) and nodular graphite iron (FNS type) is presented in table II [1,5 and 6].

The chemical composition include both the basic elements (C, Si, Mn, S, P), and the alloying elements ( $\mathrm{Cr}, \mathrm{Ni}, \mathrm{Mo}$ ), as well as the magnesium content (in the case of nodular-irons). In special cases, these irons can contain up to 0.15-0.2\% vanadium. ${ }^{[1,5}$ and 6$]$ Also, in the case of elaboration of irons with nodular graphite, destined to casting rolls (FNS type), a higher content of phosphorus is accepted, because this chemical element participates at the hardening of the rolling surface of the rolls ${ }^{[1,5}$ and 6$]$.

\section{RESULTS OF ANALYSES}

In the case of the medium-hard cast iron rolls, the chrome has a less important influence than in the

Table I. The recommended hardness of the medium-hard cast-iron rolls

Tabla I. Dureza recomendada de cilindros de fundición de media dureza

\begin{tabular}{|c|c|c|c|c|c|}
\hline \multirow{3}{*}{$\begin{array}{l}\text { Analyzed } \\
\text { roll types }\end{array}$} & \multirow{3}{*}{$\begin{array}{c}\text { Hardness } \\
\text { Class }\end{array}$} & \multicolumn{4}{|c|}{ Recommended hardness of rolls } \\
\hline & & \multicolumn{2}{|c|}{ on the working surface } & \multicolumn{2}{|c|}{ on the core and the necks } \\
\hline & & [Shore Hardness] & [Brinell Hardness] & [Shore Hardness] & [Brinell Hardness] \\
\hline FNS & 0 & $33-42$ & $218-286$ & $30-40$ & $195-271$ \\
\hline FNS & 1 & $43-59$ & $294-347$ & $30-40$ & $195-271$ \\
\hline FS & 2 & $59-68$ & $420-491$ & $35-45$ & 218-309 \\
\hline FNS & 2 & $69-75$ & $499-550$ & $35-45$ & 218-309 \\
\hline
\end{tabular}

Table II. The recommended chemical composition of the medium-hard cast-iron rolls

Tabla II. Composición química recomendada de cilindros de laminación de media dureza

\begin{tabular}{|c|c|c|c|c|c|c|c|c|c|}
\hline \multirow{2}{*}{$\begin{array}{l}\text { Rolls } \\
\text { Types }\end{array}$} & \multicolumn{9}{|c|}{ Chemical Composition, [ \% ] } \\
\hline & $\mathrm{C}$ & Si & $\mathrm{Mn}$ & $P$ & S & $\mathrm{Ni}$ & $\mathrm{Cr}$ & Mo & $\mathrm{Mg}$ \\
\hline FS & $2.9-3.6$ & $0.3-1.2$ & $\max 0.6$ & $\max 0.15$ & $\max 0.1$ & $\max 0.6$ & $\max 0.5$ & $0.3-0.5$ & - \\
\hline FNS & $3.0-3.5$ & $1.2-2.5$ & $0.1-0.7$ & $\max 0.15$ & $\max 0.02$ & 1.5-2.5 & $\max 0.8$ & $0.3-0.5$ & $0.02-0.04$ \\
\hline
\end{tabular}


case of hard and high-hard rolls, as in their case the chrome proves to be the most efficient alloying element to regulate the crust depth. The mediumhard rolls have chrome content, which is preserved at low limits (a maximum of $0.6 \%$ ), although this content still assures the necessary hardness on the rolling surface and in the core the rolls. According to the practical values, an increase of the hardness is to notice, together with a growth of the chrome content ${ }^{[1,5,6,10,12 \text { and } 15]}$.

The nickel addition leads to the improvement of the mechanical properties (resistance at wear, resistance at thermal shock, hardness and upon the workability of the cast rolls). If we do not allow this element to increase the graphitization degrees and the white solidification in the area of the rolling surface, this content will be considerably reduced. Accordingly, the silicon content of the irons is modified, as this element replaces nickel ${ }^{[1,5}$ and 6$]$. Also, the nickel content is in close accordance with the chrome content of the irons, to favor the formation of the perlitical structure, without the massive and rough carbides. These two elements are added simultaneously, because the addition of chrome compensates the graphitizing effect of the nickel. The proportion between the nickel and the chrome is situated between 2-4[1,5 and 6]. According to the practical values, the variation is almost linear, maximum hardness being obtained at a higher limit of the recommended nickel ${ }^{[1,5,6,10,11,14 \text { and 15]. }}$.

The molybdenum is a carburigenous element, but this effect is relevant only at percentage above $0.6 \%$. Below this value, fine structures are obtained on the entire section, also an increase of the wear resistance and to high temperature stabilities, as well as a considerable mechanical resistance. The molybdenum addition in the irons composition increases both the resistance at the thermal shock and the fatigue resistance. In the molybdenum alloyed irons, contents beyond a percentage of $0.15 \%$, are not recommended, because a portion of the molybdenum is lost through the combination with the phosphorus, and the molybdenum loses a part of its alloying element function. In the case of medium-hard rolls, the content of phosphorus does not pass this limit, and is imposed by standards to 0.1-0.3\%. The analyzed nodular graphite irons present a molybdenum content, which varies between $0.18 \ldots 0.28 \%$. According to the practical values, although the marks seem dispersed, it is easy to notice the growth of hardness as the content of molybdenum increases in this interval $[1,5,6,10,11$, 14 and 15$]$.

The realization of an optimal chemical composition can constitute a technical efficient mode to assure the exploitation properties, the material from which the rolling mills rolls are manufactured having an important role in this sense. From this point of view is applied the mathematical modeling, which is achieved starting from the differentiation on rolls component parts, taking into consideration the industrial data obtained from the hardness mensuration on rolls, which recommends the hardness, for different chemical compositions.

Using the Matlab calculation and graphical programs was determinate some correlations between the hardness and the chemical composition. Using the double and triple correlations is really helpful in the foundry practice, as it allows us to determine variation boundaries for the chemical composition, in view the obtaining the desired and optimal values of the hardness's of this very important metallurgical equipments. The research it was aimed to establish calculus methodologies of values for the technological parameters in the manufacturing process of the medium-hard rolling mill rolls, obtained through the simplex classical cast of the iron with nodular graphite, for which the mechanical features of rolling mill rolls have the required values [5, 6 and 10].

\section{MATHEMATICAL INTERPRETATION AND GRAPHICAL ADDENDA}

Therefore, I suggest a mathematical interpretation of the influence of the main alloy elements over the hardness on the necks of these nodular cast iron rolls, resulting the average values and average square aberration of the variables HB (Brinell hardness), and the main alloying elements $(\mathrm{Cr}, \mathrm{Ni}, \mathrm{Mo})$, the equations of the hyper surface in the four dimensional space. For the statistical and mathematical analysis, there were used some industrial cases. For the multidimensional processing of experimental data, is searched for a method of modeling the hardness (dependent variables) depending on the main alloying elements (independent variables). ${ }^{5,11,12}$ and ${ }^{14]}$ The optimal form of modeling, studied on a sample of the cases, differentiated for the two technological zones of the rolls (necks and rolling surfaces), is given by the equations:

$$
\begin{gathered}
\mathrm{HB}_{(\text {necks })}=-781.1796 \mathrm{Cr}^{2}+43.6808 \mathrm{Ni}^{2}+ \\
603.2086 \mathrm{Mo}^{2}+149.4834 \mathrm{Cr} \cdot \mathrm{Ni}-250.0172 \\
\mathrm{Ni} \cdot \mathrm{Mo}+615.7891 \mathrm{Mo} \cdot \mathrm{Cr}+520.5551 \mathrm{Cr}- \\
70.5827 \mathrm{Ni}-228.3874 \mathrm{Mo}+201.3144
\end{gathered}
$$


RESEARCH UPON THE QUALITY ASSURANCE OF THE ROLLING-MILL ROLLS ANDTHE VARIATION BOUNDARIES OF THE CHEMICAL COMPOSITION INVESTIGACIÓN AL ASEGURAMIENTO DE CALIDAD DE LOS CILINDROS DE LAMINADOR Y DE LOS LÍMITES DE LA VARIACIÓN DE LA COMPOSICIÓN QUIIMICA

$$
\begin{gathered}
\mathrm{HB}_{\text {(rolling surface) }}=-449.6316 \mathrm{Cr}^{2}+63.5482 \\
\mathrm{Ni}^{2}+660.0506 \mathrm{Mo}^{2}-253.5251 \mathrm{Cr} \mathrm{Ni}- \\
84.7047 \mathrm{Ni} \mathrm{Mo}^{*}+177.7449 \mathrm{Mo}{ }^{*} \mathrm{Cr}+ \\
\text { 817.364 } \mathrm{Cr}-13.6043 \mathrm{Ni}-291.2341 \mathrm{Mo} \\
+260.6273
\end{gathered}
$$

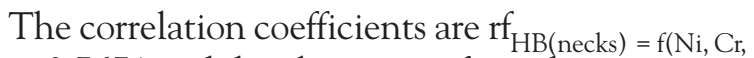
Mo) $=0.7671$ and the aberrations from the regression surface are $\mathrm{sf}_{\mathrm{HB}(\mathrm{necks})}=\mathrm{f}(\mathrm{Ni}, \mathrm{Cr}, \mathrm{Mo})=8.7376$.

In the technological field, the behavior of these hyper surfaces in the vicinity of the saddle point, or of the point where three independent variables take their average value, can be studied only tabular, which means that the independent variables are attributed values on spheres concentric to the studied point. Because these surfaces cannot be represented in the three-dimensional space, the independent variables were successively replaced with their average values. This is how the following equations were obtained.

$$
\begin{gathered}
\mathrm{HB}_{(\text {necks) }} \mathrm{Ni}_{\text {med }}=43.6808 \mathrm{Ni}^{2}+603.2086 \mathrm{Mo}^{2} \\
-250.0172 \mathrm{Ni} \cdot \mathrm{Mo}+3.8341 \mathrm{Ni}+78.1684 \mathrm{Mo} \\
+266.8599 \\
\mathrm{HB}_{(\text {necks) }} \mathrm{Cr}_{\text {med }}=603.2086 \mathrm{Mo}^{2}-781.1796 \\
\mathrm{Cr}^{2}+615.7891 \mathrm{Mo} \cdot \mathrm{Cr}-566.7802 \mathrm{Mo}+ \\
722.8777 \mathrm{Cr}+185.8013 \\
\mathrm{HB}_{(\text {necks) }} \mathrm{Mo}_{\text {med }}=-781.1796 \mathrm{Cr}^{2}+43.6808 \\
\mathrm{Ni}^{2}+149.4834 \mathrm{Cr} \cdot \mathrm{Ni}+749.7357 \mathrm{Cr}- \\
163.6326 \mathrm{Ni}+199.8671
\end{gathered}
$$

Respectively,

$$
\begin{gathered}
\mathrm{HB}_{\text {(rolling surface) }} \mathrm{Ni}_{\text {med }}=660.0506 \mathrm{Mo}^{2}- \\
\text { 449.6316 Cr}{ }^{2}+177.7449 \mathrm{Mo}^{*} \mathrm{Cr}- \\
541.2281 \mathrm{Mo}+474.2232 \mathrm{Cr}+358.6283(6)
\end{gathered}
$$

$$
\begin{gathered}
\mathrm{HB}_{(\text {rolling surface) }} \mathrm{Cr}_{\text {med }}=63.5482 \mathrm{Ni}^{2}+ \\
660.0506 \mathrm{Mo}^{2}-184.7047 \mathrm{Ni}^{*} \mathrm{Mo}- \\
139.8157 \mathrm{Ni}-202.7481 \mathrm{Mo}+556.0999(7)
\end{gathered}
$$$$
\mathrm{HB}_{\text {(rolling surface) }} \mathrm{Mo}_{\text {med }}=-449.6316 \mathrm{Cr}^{2}+
$$$$
63.5482 \mathrm{Ni}^{2}-253.5251 \mathrm{Cr}^{*} \mathrm{Ni}+
$$$$
883.5161 \mathrm{Cr}-82.3466 \mathrm{Ni}+243.6635
$$

These surfaces, belonging to the three-dimensional space, can be represented and, therefore, interpreted by technologists. Knowing these level curves allows the correlation of the values of the twos independent variables so that the hardness can be obtained in between the requested limits ${ }^{[5,12}$ and 15$]$.

\section{THE TECHNOLOGICAL DOMAIN}

The existence of a saddle point inside the technological domain has a particular importance as it ensures stability to the process in the vicinity of this point, stability which can be either preferable of avoidable ${ }^{[5]}$.

The behavior of this hyper surface in the vicinity of the stationary point (when this point belongs to the technological domain) or in the vicinity of the point where the three independent variables have their respective mean value, or in a point where the dependent function reaches its extreme value in the technological domain (but not being a saddle point) can be rendered only as a table, namely, assigning values to the independent variables on spheres which are concentrically to the point under study ${ }^{[5,12 \text { and } 15]}$. As this surface cannot be represented in the three-dimensional space, we resorted to replacing successively one independent variable by its mean value. These surfaces (described by the equation 3-5 and 6-8), belonging to the threedimensional space can be reproduced and therefore interpreted by technological engineers. The regression surfaces $\mathrm{HB}_{\text {(necks) }}$ for the middle value of the $\mathrm{Cr}, \mathrm{Ni}$ and Mo (case of the necks) are presented in figure 1. Also, the regression surfaces $\mathrm{HB}_{\text {(rolling sufface) }}$ for middle value of $\mathrm{Cr}, \mathrm{Ni}$ and $\mathrm{Mo}$ (case of the surface) are showing in the figure 2 .

The level curves represent the projections of the regression surfaces in the two-dimensional plane and can be diagrams described for the middle value of the parameters $\left(\mathrm{Cr}_{\text {med }}, \mathrm{Ni}_{\text {med }}, \mathrm{Mo}_{\text {med }}\right)$. This geometrical area represents level curves variations in the two-dimensional plan. The level curves for the middle value of the $\mathrm{Cr}, \mathrm{Ni}$ and $\mathrm{Mo}$ are presented in figure 3 (case of the necks) and figure 4 (case of the surface). These diagrams are built for the average values of the parameters, only that through the representation of the diagrams for parameters values contained in the variations limits we can obtain adjusting diagrams, with which we can completely controlled the process.

The graphical addenda represents some surfaces which accept as stability points, extremely points (minimal or maximal) or inflexion point. The coordinates of these points are included in the technological domain, are in the vicinity of the technological limits, or can be situated much outside of this area (represented by the level curves or by the color maps). Therefore, the variation domains are divided in some subdomains which bordered the optimal domains (see in Fig. 3 and Fig. 4). The color maps for the middle value of the $\mathrm{Cr}, \mathrm{Ni}$ and $\mathrm{Mo}$ are presented in figure 5 (case of the necks) and in figure 6 (case of the surface). These optimal domains, 

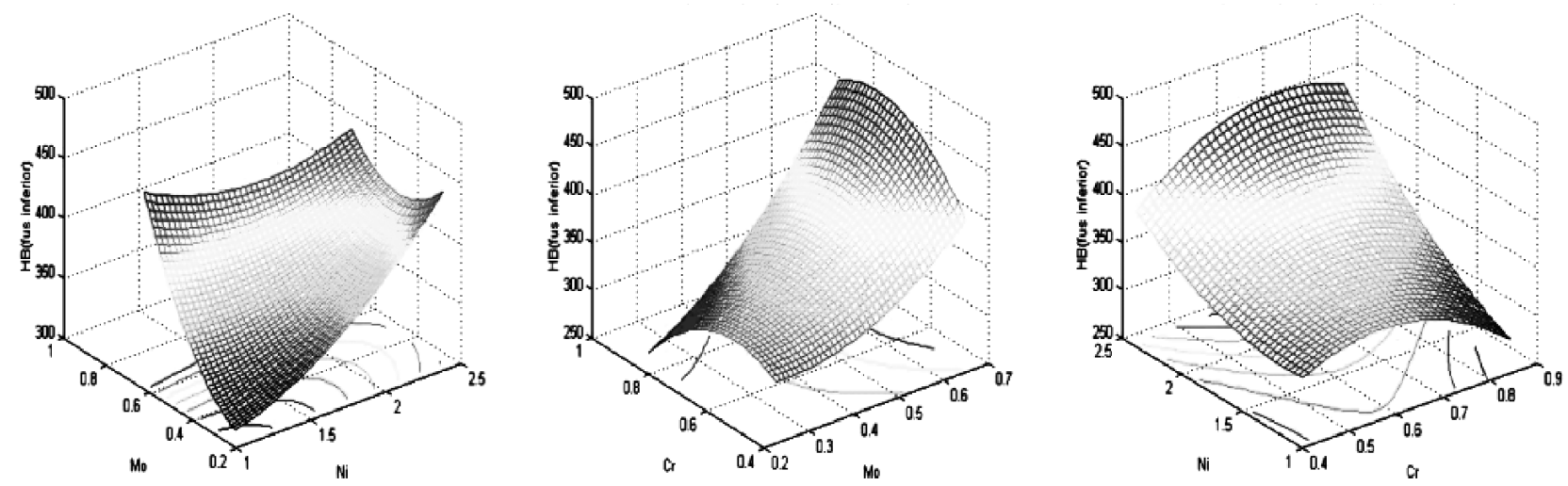

Figure 1. The regression surfaces $\mathrm{HB}_{(\text {necks) }}$ for the middle value of the $\mathrm{Cr}$, $\mathrm{Ni}$ and $\mathrm{Mo}$ (case of the necks).

Figura 1. Superficies de regresión $H B_{(\text {necks) }}$ para el valor medio del Cr, Ni y Mo (caso de los cuellos).
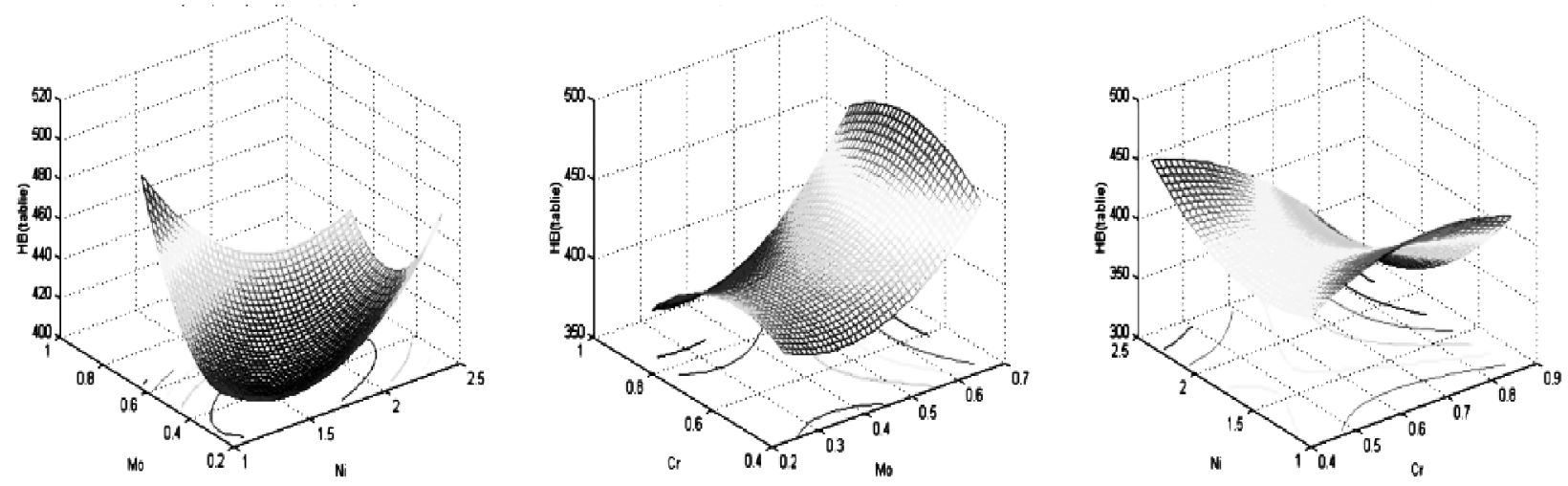

Figure 2. The regression surfaces $\mathrm{HB}_{\text {(rolling surface) }}$ for middle value of $\mathrm{Cr}$, Ni and $\mathrm{Mo}$ (case of the surface). Figura 2. Superficies de regresión $\mathrm{HB}_{\text {(rolling surface) }}$ para el valor medio del Cr, Ni y Mo (caso de la superficie).
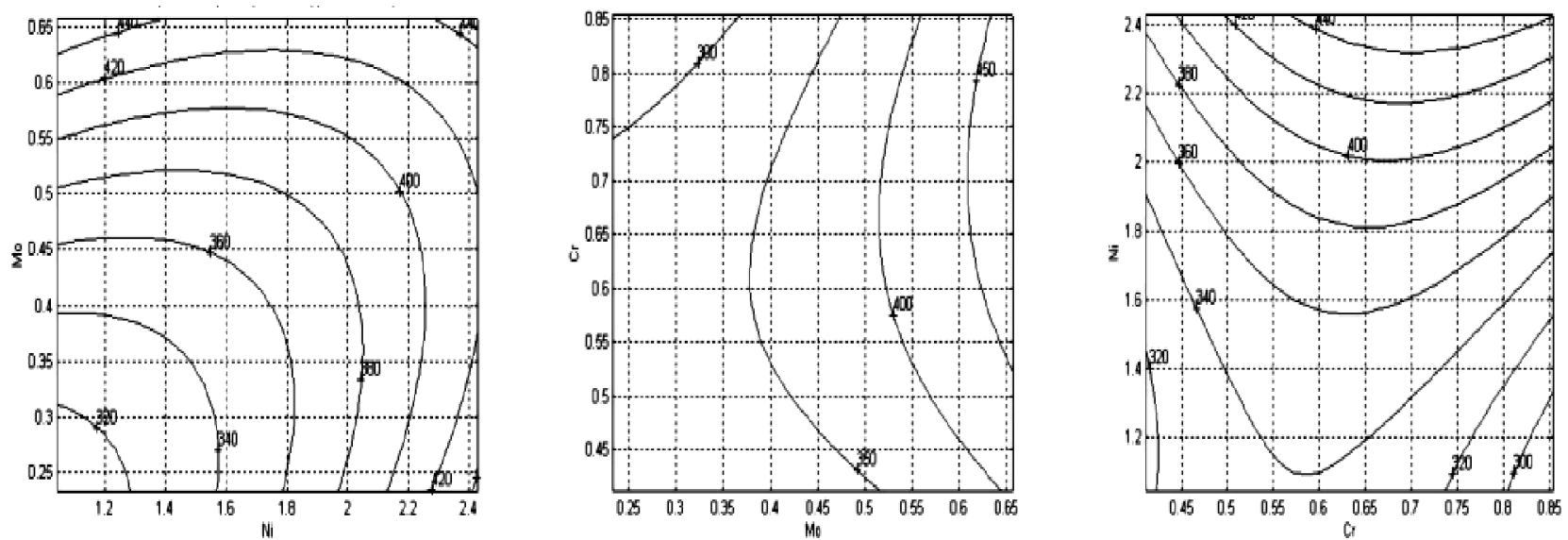

Figure 3. The level curves for the middle value of the $\mathrm{Cr}$, Ni and $\mathrm{Mo}$ (case of the necks).

Figura 3. Curvas del nivel para el valor medio del Cr, Ni y Mo (caso de los cuellos). 
RESEARCH UPON THE QUALITY ASSURANCE OF THE ROLLING-MILL ROLLS ANDTHE VARIATION BOUNDARIES OF THE CHEMICAL COMPOSITION INVESTIGACIÓN AL ASEGURAMIENTO DE CALIDAD DE LOS CILINDROS DE LAMINADOR Y DE LOS LÍMITES DE LA VARIACIÓN DE LA COMPOSICIÓN QUÍMICA
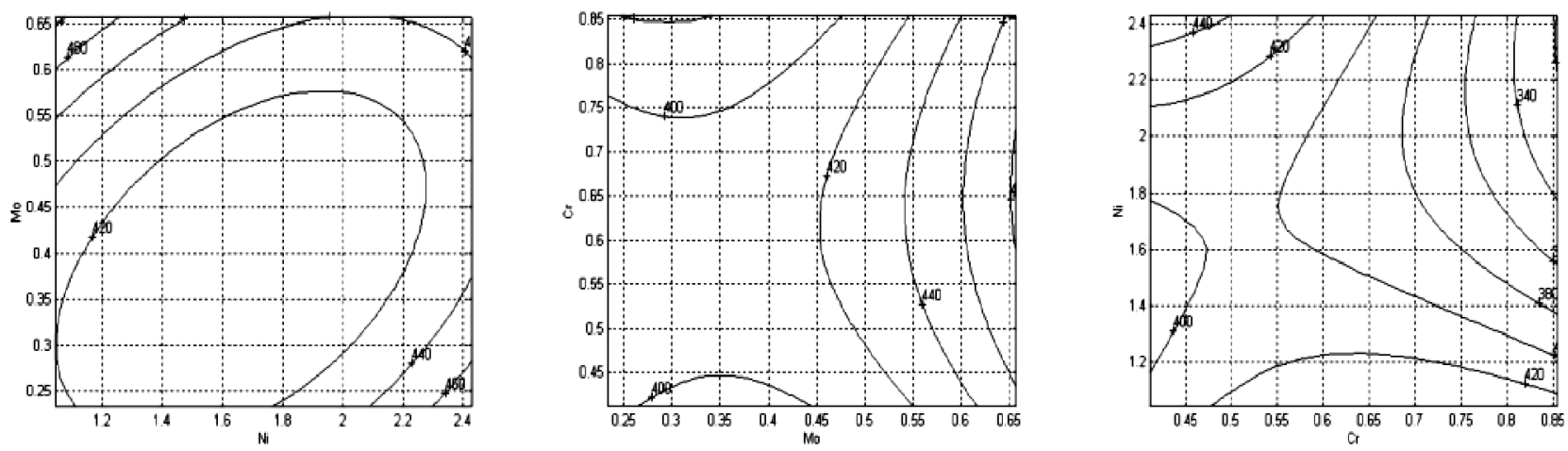

Figure 4. The level curves for the middle value of the $\mathrm{Cr}$, Ni and Mo (case of the surface).

Figura 4. Curvas del nivel para el valor medio de Cr, Ni y Mo (caso de la superficie).
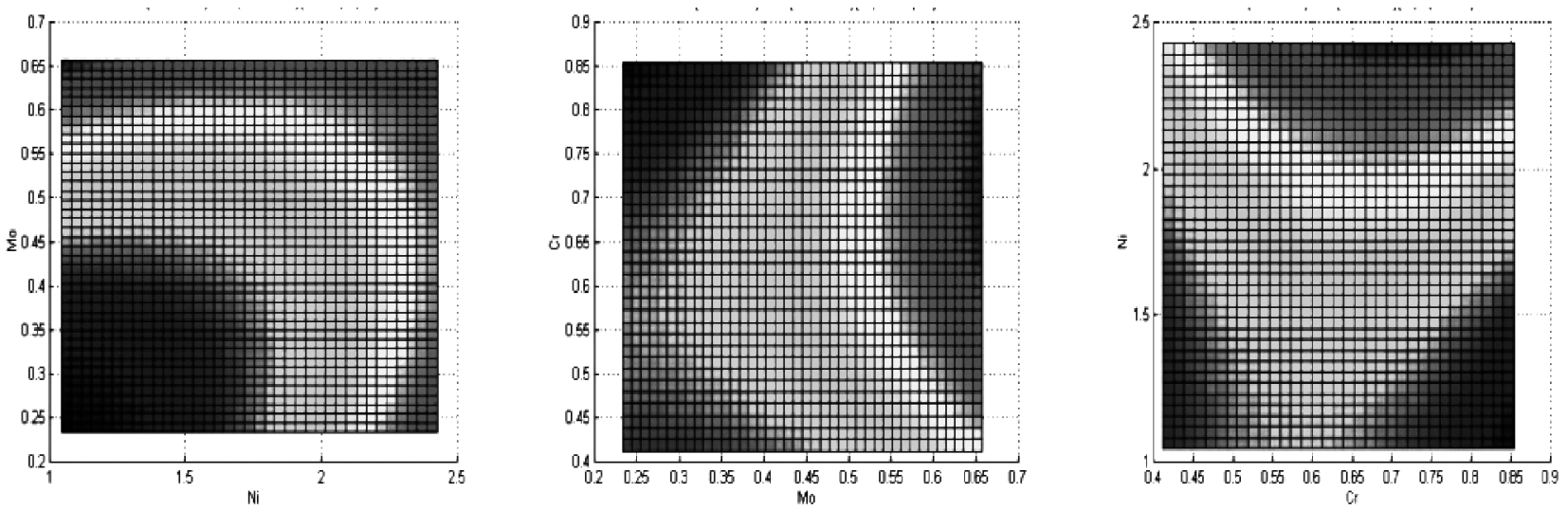

Figure 5. The color map for the middle value of the $\mathrm{Cr}$, Ni and $\mathrm{Mo}$ (case of the necks).

Figura 5. Mapa de color del valor medio de Cr, Ni y Mo (caso de los cuellos).
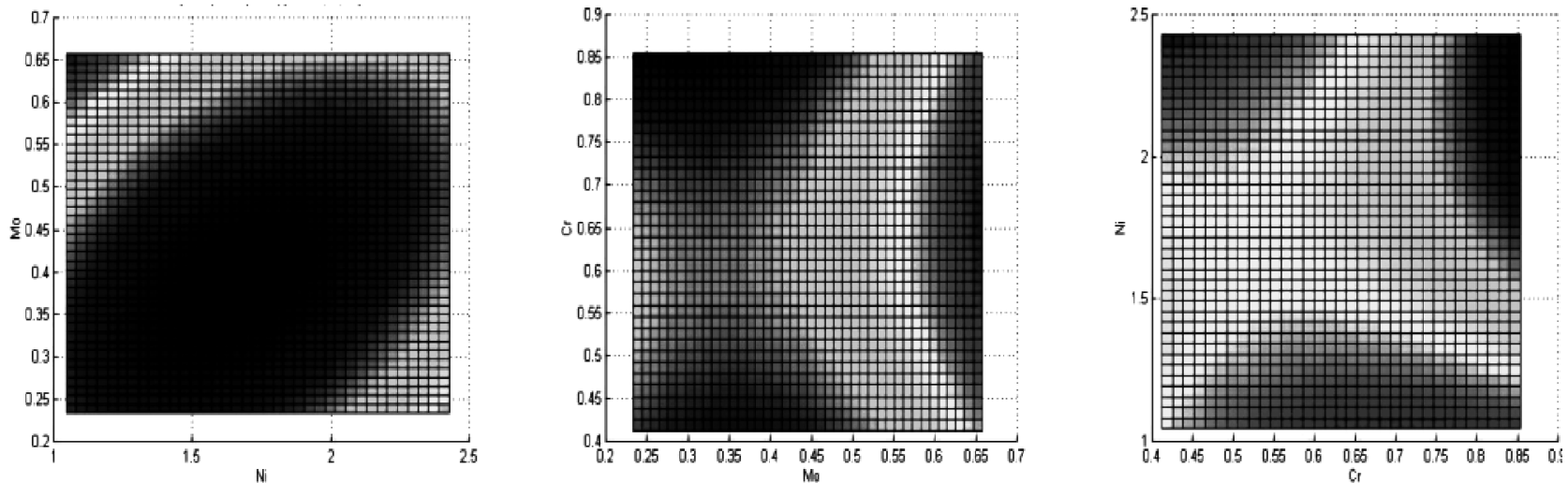

Figura 6. The color map for the middle value of the $\mathrm{Cr}$, Ni and Mo (case of the surface).

Figura 6. Mapa de color del valor medio de Cr, Ni y Mo (caso de la superficie).

and also, the sub domains, can be represented by the program through the significantly level curves or by the color maps. These representations can be interpreted by the technological engineers, and can be an important reference for the optimal drives of the technological processes in foundries. Knowing 
these level curves, described for the rolling cylinders body and necks allows the correlation of the values of the two independent variables so that we can obtain the hardness within the required limits.

\section{CONCLUSIONS}

Starting from the lamination equipments aspects, from the form of cylinders, the technological interest zones and the structure, which assures the exploitation property, it was establish, through modeling, to the mathematical description of a direct influences. This article explains how the chemical composition, through the main alloying elements $(\mathrm{Ni}, \mathrm{Cr}, \mathrm{Mo})$, influencing on a structure and the expected mechanical properties of the nodular cast irons, and presents also some graphical addenda. We suggest a mathematical shaping of the influence of the main alloy elements over the mechanical characteristics (the hardness on the crust of the rolls) of this nodular irons, resulting the average values and average square aberration of the variables $\mathrm{HB}$, and the main alloying elements (Cr, Ni, Mo), the equations of the hyper surface in the four dimensional space. For the statistical and mathematical analysis, there were used the industrial cases. The usage of the Matlab area can also be extended to the study of influences other elements of the basic chemical compositions $(\mathrm{C}, \mathrm{Si}$, $\mathrm{Mn}, \mathrm{S}, \mathrm{P}, \mathrm{Mg}$ ).

Through the original aimed elements mentioned above, the research allows the enunciation of new approaches in the area afferent to the theme. The applicative research activity is directed to the knowledge broadening in order to use this knowledge for developing new technological processes or for improving significantly the existing technological processes. These results are of immediate practical utility both to the cast-iron rolling mills cylinders manufacturing industry, and to the rolling sectors. In this sense, these researches results can be used in the collective framework of the foundries and the rolling mills sectors, for assurances quality of rolls as far back as phase of production, as well as in their exploitation, what lead to the assurance quality of produced laminates.

The realization of a mathematical model starting from industrial data, gathered at the cylinders hardness measurement, and at the national standards, which recommends the hardness, for different chemical compositions, also determines the degree of originality of the research. The determination of the equations of regression hiperplanes, which describe the mathematical dependency between the chemical composition and the hardness, the determination of the multi-component relations and the realization of the graphic interfaces for the representations variation areas of the cast-irons chemical composition, completes this area of preoccupations within the processing of mathematical modeling and optimization.

\section{REFERENCES}

[1] N.A. Budaghianțt and V.E. Karsski, Cilindrii de laminor turnaţi, Ed. Tehnică, Bucureşti, 1986.

[2] Gh. Chelu, Modelarea şi optimizarea proceselor de prelucrare plastică la cald, Ed. BREN, Bucureşti, 2000.

[3] M. Ghinea and V. Firețeanu, Matlab. Calcul numeric - grafică - aplicaţii, Ed. Teora, Bucureşti, 1999.

[4] D. Taloi, C. Bratu, E. Florian and E. Berceanu, Optimizarea proceselor metalurgice, Ed. Didactică şi Pedagogică, Bucureşti, 1983.

[5] I. Kiss, the quality of rolling mills rolls cast by iron with nodular graphite, Mirton, Timisoara, 2005.

[6] *** Romanian Standards for cast-iron rolling mills rolls.

[7] C. Pinca-Bretotean, I. Kiss, T. Heput and O. Tirian, J. Mech. Eng. 3 (2004) 177-188.

[8] I. Ripoşan, V. Docean and A. Mitrofan, Metal. 3 (1989) 138-142.

[9] L. Sofroni, Metal. 10 (1983) 397-408.

[10] L. Sofroni, I. Ripoșan, I. Chira and V. Brabie, Metal. 10 (1983) 473-478.

[11] I. Kiss and St. Maksay, Metalurgia Int. 2 (2005) 14-21.

[12] I. Kiss and St. Maksay, $6^{\text {th }}$ Int. Symp. Young People Multidisciplinary Research, Sudura Printing House, Timisoara, 2004, pp. 176-185.

[13] I. Kiss and St. Maksay, J. Mech. Eng. 1 (2005) 17-22.

[14] I. Kiss, I. Ripoşan and St. Maksay, Ann. Fac. Eng. Hunedoara 2 (2005) 193-201.

[15] I. Kiss, V. Alexa and S. Ratiu, $4^{\text {th }}$ Int. Symp. KOD, Palic, Serbia and Montenegro, 2006

[16] I. Kiss and St. Maksay, Ann. Fac.Eng. Hunedoara 4 (2006) 77-82. 